\title{
Aplikasi Sistem Informasi E-Culture Kabupaten SITARO Berbasis Web
}

\author{
Manuho, R. ${ }^{1)}$, Rindengan, Y.D. ${ }^{2)}$, Sinsuw, A.A.E. ${ }^{3)}$ \\ 1,2,3 Teknik Informatika Universitas Sam Ratulangi Manado, Indonesia. \\ 120216023@student.unsrat.ac.id ${ }^{1)}$, rindengan@unsrat.ac.id ${ }^{2)}$, alicia.sinsuw@unsrat.ac.id ${ }^{3)}$
}

\begin{abstract}
Abstrak — Budaya merupakan satu unsur penting sebagai ciri khas dan identitas dalam suatu Negara. Sebagai anak-anak bangsa kita perlu mengetahui den mengenal setiap suku dan budaya yang ada. Perkembangan yang sangat pesat saat ini membuat arus kebutuhan dalam dunia teknologi informasi turut berkembang dengan cepat. Internet sebagai salah satu media untuk mendapatkan informasi juga semakin mudah diakses dari mana saja. Terkadang masyarakat tidak mengenal budaya di daerah mereka sendiri. Untuk itu pengetahuan tentang Ragam Budaya Indonesia perlu di terapkan ke dalam bentuk sistem informasi berbasis web agar memberikan pemahaman tentang Ragam Budaya Indonesia. Metode Aplikasi Sistem Informasi e-culture KAB. SITARO berbasis web adalah rapid application development (RAD) tujuan utamanya adalah memenuhi harapan dari pengguna dengan waktu yang realtif singkat dan mengahasilkan kualitas sistem yang lebih baik.
\end{abstract}

Kata Kunci : E-culture, kebudayaan, sistem

informasi, website, $R A D$

\section{PENDAHULUAN}

Indonesia memiliki budaya yang berbeda-beda di setiap daerah, namun tidak banyak masyarakat yang mengetahui atau mengenali budaya mereka masing-masing. Kata kebudayaan berasal dari kata Sanskerta buddhayah, bentuk jamak dari buddhi yang berarti "budi" atau "kekal"

Budaya merupakan satu unsur penting sebagai ciri khas dan identitas dalam suatu Negara. Sebagai anak-anak bangsa kita perlu mengetahui dan mengenal setiap suku dan budaya yang ada.

Kabupaten Kepulauan Siau Tagulandang Biaro atau yang disingkat Kabupaten SITARO adalah sebuah Kabupaten di Provinsi Sulawesi Utara, Indonesia beribukota di Ondong Siau.

Kebudayaan di Sitaro ada beberapa, diantaranya : - Kebudayaan seni yaitu : Masamper, orkes, musik bambu, tari gunde. - Kebudayaan adat yaitu : Tulude dan Mulikubanua. - Kebudayaan cerita rakyat yaitu : Asal usul nama Pulau Siau, asal mula tradisi Tamo, kisah Raksasa Onding, kisah Sense Madunde, dan Ake Sio.
Perkembangan yang sangat pesat saat ini membuat arus kebutuhan dalam dunia teknologi informasi turut berkembang dengan cepat. Internet sebagai salah satu media untuk mendapatkan informasi juga semakin mudah diakses dari mana saja. Dengan berkembangnya teknologi internet, masyarakat semakin dimudahkan dalam melakukan segala macam aktivitas dan maupun mendapatkan pengetahuan tentang suatu hal. Internet bisa diakses dan dimanfaatkan untuk berbagai keperluan, oleh siapa saja, kapanpun kita mau menggunakannya.

Terkadang masyarakat tidak mengenal budaya di daerah mereka sendiri. Untuk itu pengetahuan tentang Ragam Budaya Indonesia perlu di terapkan ke dalam bentuk sistem informasi berbasis web agar memberikan pemahaman tentang Ragam Budaya Indonesia. Karena budaya merupakan identitas bangsa yang harus dihormati dan dijaga, serta perlu dilestarikan agar kebudayaan kita tidak hilang dan bisa menjadi warisan anak cucu kita kelak.

Hal ini tentu menjadi tanggung jawab para kita generasi muda dan juga perlu dukungan dari berbagai pihak, karena ketahanan budaya merupakan salah satu identitas suatu negara.

Selain sebagai sumber informasi dan juga untuk melestarikan kebudayaan Indonesia bagi masyarakat yang kurang pemahaman tentang ragam kebudayaan yang ada di Indonesia, khususnya yang ada di Kabupaten Kepulauan SITARO. Berbagai macam teknologi internet bisa digunakan, salah satunya adalah World Wide Web (atau disebut juga dengan "web") yang mampu menyediakan informasi dalam bentuk teks, gambar, suara, maupun gambar bergerak. Dengan kemampuan seperti ini, web menjadi sangat terkenal dan perkembangannya sangatlah pesat. Setiap orang pasti mengakses internet setiap harinya, sehingga membuat web berkembang pesat di era modern saat ini. Perkembangan web yang semakin pesat memicu berbagai macam orang maupun komunitas untuk memiliki sistem informasi berbasis web yang dapat memudahkan siapa saja dalam memberikan informasi tentang kebudayaan untuk dapat diketahui oleh masyarakat dengan baik, serta informasi yang dihasilkan dapat diakses secara mudah. 


\section{LANDASAN TEORI}

A. Kebudayaan

Pengertian Kebudayaan ada beberapa pengertian kebudayaan menurut beberapa ahli, salah satu diantaranya adalah tokoh terkenal Indonesia yaitu Koentjaraningrat. Menurut Koentjaraningrat mendefinisikan budaya dengan kata dasar budaya berasal dari bahasa sansekerta "buddhayah", yaitu bentuk jamak dari buddhi yang berarti "budi" atau "akal". Jadi Koentjaraningrat mendefenisikan budaya sebagai "daya budi" yang berupa cipta, karsa, dan rasa itu.

Dalam bahasa Inggris, kebudayaan disebut culture, yang berasal dari kata Latin Colere, yaitu mengolah atau mengerjakan. Kata culture juga kadang diterjemahkan sebagai "kultur" dalam bahasa Indonesia. Menurut Tylor, culture atau kebudayaan adalah keseluruhan aktivitas manusia, termasuk pengetahuan, kepercayaan, seni, moral, hukum adatistiadat, dan kebiasan-kebiasan lain.

Definisi lain dikemukakan oleh Harris, Marvin yaitu seluruh aspek kehidupan manusia dalam masyarakat, yang diperoleh dengan cara belajar, termasuk pikiran dan tingkah laku.

Definisi lain menurut Peraturan Menteri Pendidikan dan Kebudayaan Republik Indonesia nomor 52 Tahun 2014, kebudayaan sebagai keseluruhan gagasan, perilaku, dan hasil karya manusia dan/atau kelompok manusia yang dikembangkan melalui proses belajar dan adaptasi terhadap lingkungannya yang berfungsi sebagai pedoman untuk kehidupan bermasyarakat, berbangsa, dan bernegara.

1) Kebudayaan Cerita Rakyat

Cerita Rakyat adalah sebagian kekayaan budaya dan sejarah yang dimiliki Bangsa Indonesia. Pada umumnya, cerita rakyat mengisahkan tentang suatu kejadian di suatu tempat atau asal muasal suatu tempat. Tokoh-tokoh yang dimunculkan dalam cerita rakyat umumnya diwujudkan dalam bentuk binatang, manusia maupun dewa. (Dedi,2010). Cerita rakyat merupakan salah satu budaya lokal. Di dalamnya berisi seperangkat nilai etika, estetika, yang menjadi pedoman perilaku manusia dalam mewujudkan caracara hidup. Sebagai warisan budaya, maka masyarakat mempelajarinya dan mematuhi normanorma serta menjujung tinggi nilai-nilai yang ada. Dalam pengembangannya, cerita rakyat merupakan bagian dari sistem kesenian ini didukung oleh unsurunsur kebudayaan lain.

2) Kebudayaan Adat

Menurut kamus umum bahasa Indonesia adat mempunyai beberapa makna di antaranya, adat diartikan sebagai cara(kelakuan) yang sudah menjadi kebiasaan. Yang kedua adat diartikan sebagai wujud gagasan kebudayaan yang terdiri atas nilai-nilai budaya, norma, hukum, dan aturan-aturan yang satu dengan yang lainnya berkaitan menjadi satu sistem. Sedangkan yang berikutnya adat istiadat adalah tata kelakuan yang kekal dan turun temurun dari generasi ke generasi lain sebagai warisan sehingga kuat integrasinya dengan pola-pola perilaku masyarakat ( Kamus besar bahasa Indonesia, 1988:5,6). Sinonim dari istilah adat istiadat adalah tradisi,arti tradisi yang paling mendasar yaitu sesuatu yang diteruskan(transmitted) dari masa lalu ke masa sekarang, bisa berupa benda, nilai, norma, harapan, dan cita-cita. Dalam hal ini tidak dipermasalahkan berapa lama unsur-unsur tersebut dibawah dari satu generasi ke generasi berikutnya. Kriteria yang paling menentukan bagi konsepsi tradisi itu adalah bahwa tradisi diciptakan melalui tindakan dan kelakukan orang-orang melalui fikiran dan imajinasi orangorang yang diteruskan dari satu generasi ke generasi berikutnya (Skils dalam Sayogyo, 1985:90).

3) Kebudayaan seni

Seni memiliki fungsi yang dapat dirasakan secara langsung maupun tidak langsung bagi manusia. Fungsi yang secara langsung dapat dirasakan adalah sebagai media untuk berekspresi diri, berkomunikasi, bermain, dan menyalurkan bakat yang dimiliki secara tidak langsung, manusia dapat memperoleh manfaat pendidikan melalui pengembangan berbagai kemampuan dasarnya untuk belajar. Selain itu, melalui pendidikan seni manusia dapat memperoleh kehalusan budi pekerti, karena seni mengolah kepekaan manusia terhadap alam dan lingkungan sekitar serta hal-hal yang berkaitan dengan keindahan. Kemampuan dasar manusia yang dapat dikembangkan melalui seni meliputi perkembangan fisik yang berkaitan dengan kegiatan seni adalah kemampuan gerak. Gerak/motorik dapat dibedakan menjadi motorik kasar dan motorik halus. Seni banyak terkait dengan motorik halus. Menggambar, membentuk, serta menggerakan jari sewaktu menari dan memainkan alat musik merupakan gerak motorik halus. Gerak kepala, tangan, kaki, dan tubuh saat menari dan memainkan peran adalah motorik kasar. Melalui seni, kemampuan motorik manusia bisa berkembang. Seni yaitu ekspresi perasaan manusia yang memiliki unsur keindahan didalamnya, dan diungkapkan melalui suatu media yang sifatnya nyata, baik itu dalam bentuk nada, rupa gerak, dan syair, serta dapat dirasakan oleh panca indera manusia.

\section{B. E-culture}

Menurut Dirk dan Esmans e-Culture (Electronic Culture) mengacu pada hubungan antara Teknologi Informasi dan Komunikasi (TIK) dan media digital di satu sisi, dan produksi dan konsumsi seni budaya. Dengan munculnya media digital disektor seni dan 
budaya menciptakan bentuk seni baru dan kemungkinan baru untuk produksi, presentasi dan pengarsipan seni dan produk budaya. ICT mengubah cara kita menciptakan budaya, menyebarkan, melestarikan dan berpartisipasi. Pengertian ini menunjukkan bahwa ada dua hal dalam mengartikan e-culture yaitu gaya hidup masyarakat yang berbasis pada teknologi digital dan mendigitalisasikan atau mengelektronisasikan unsur-unsur budaya. Sama halnya dikemukan oleh Mahyudin Al Mudra, SH.,MM sebagai pemimpin melayuonline.com, disiarkan di Metro TV tanggal 10 agustus 2008 bahwa e-culture adalah pelestarian warisan budaya melalui teknologi informasi dan komunikasi. Eculture juga merupakan bagian dari e-life style, yaitu gaya hidup masyarakat yang berbasis teknologi digital. Lebih lanjut Mahyudin mengatakan budaya elektronik secara perlahan telah menggantikan budaya tradisional yang dianggap kurang up to date. e-Culture pada gilirannya akan membentuk budaya baru, oleh karena apa yang disampaikan melalui media internet akan menyebar ke pemirsa di manapun mereka berada. Jika masyarakat yang sudah memperoleh informasi ini kemudian menyebarkannya kepada masyarakat yang luas, maka proses pembentukan budaya baru itupun berlangsung. Sementara Sitokdana, M.N.N mengartikan digitalisasi kebudayaan sebagai suatu konsep pemanfaatan teknologi informasi dan komunikasi untuk meningkatkan daya guna dalam bidang kebudayaan, terutama dalam hal pengelolaan, pendokumentasian, penyebarluasan informasi dan pengetahuan dari unsur-unsur kebudayaan. Pengertian tersebut memiliki hubungan yang sangat substansial dengan e-culture. Dengan demikian dapat disimpulkan bahwa e-culture adalah mengelektronikan warisan kebudayaan dan pembentukan budaya baru melalui cipta, karsa dan rasa berbasis teknologi informasi dan komunikasi.

C. Sistem

Pengertian Sistem menurut para Ahli

1) Pengertian Sistem menurut Fat, pengertian sistem adalah sebagai berikut: "Sistem adalah suatu himpunan suatu "benda" nyata atau abstrak (a set of thing) yang terdiri dari bagian - bagian atau komponen - komponen yang saling berkaitan, berhubungan, berketergantungan, saling mendukung, yang secara keseluruhan bersatu dalam satu kesatuan (Unity) untuk mencapai tujuan tertentu secara efisien dan efektif".

2) Pengertian Sistem menurut Indrajit (2001:2), Sistem adalah kumpulan-kumpulan dari komponen-komponen yang memiliki unsur keterkaitan antara satu dengan lainnya.
3) Pengertian Sistem menurut Jogianto (2005:2), Sistem adalah kumpulan dari elemen-elemen yang berinteraksi untuk mencapai suatu tujuan tertentu. Sistem ini menggambarkan suatu kejadian-kejadian dan kesatuan yang nyata, seperti tempat, benda dan orang-orang yang betul-betul ada dan terjadi.

4) Pengertian Sistem menurut Murdick, R. G (1991:27), Sistem adalah seperangkat elemen yang membentuk kumpulan atau prosedurprosedur atau bagan-bagan pengolahan yang mencari suatu tujuan bagian atau tujuan bersama dengan mengoperasikan data dan/atau barang pada waktu rujukan tertentu untuk menghasilkan informasi dan/atau energi dan/atau barang.

5) Pengertian Sistem menurut Jerry FutzGerald, $(1981 ; 5)$ Sistem adalah suatu jaringan kerja dari prosedur - prosedur yang saling berhubungan, berkumpul bersama - sama untuk melakukan suatu kegiatan atau untuk menyelesaikan suatu sasaran yang tertentu.

6) Pengertian Sistem menurut Davis, G. B (1991:45), Sistem adalah kumpulan dari elemenelemen yang beroperai bersama-sama untuk menyelesaikan suatu sasaran.

7) Definisi Sistem menurut Dr. Ir. Harijono Djojodihardjo (1984:78) "Suatu sistem adalah sekumpulan objek yang mencakup hubungan fungsional antara tiap - tiap objek dan hubungan antara ciri tiap objek, dan yang secara keseluruhan merupakan suatu kesatuan secara fungsional".

8) Definisi Sistem menurut Lani Sidharta (1995:9), Sistem adalah himpunan dari bagian-bagian yang saling berhubungan, yang secara bersama mencapai tujuan-tujuan yang sama.

D. Informasi

Informasi adalah data yang diolah menjadi bentuk yang lebih berguna dan lebih berarti bagi penerimanya. Sumber informasi adalah data. Data kenyataan yang menggambarkan suatu kejadiankejadian dan kesatuan nyata. Kejadian-kejadian (event) adalah kejadian yang terjadi pada saat tertentu. Menurut Gordon B. Davis: Informasi adalah data yang telah diolah menjadi suatu bentuk yang penting bagi si penerima dan mempunyai nilai nyata atau yang dapat dirasakan dalam keputusankeputusan yang sekarang atau keputusan-keputusan yang akan datang.

1) Fungsi Informasi

Fungsi utamanya, yaitu : menambah pengetahuan atau mengurangi ketidakpastian pemakai informasi, karena informasi berguna memberikan gambaran tentang suatu permasalahan sehingga pengambil keputusan dapat menentukan keputusan lebih cepat, informasi juga memberikan 
standart, aturan maupun indikator bagi pengambil keputusan.

2) Kegunaan Informasi tergantung pada :

a. Tujuan si penerima :

Bila tujuannya untuk memberi bantuan, maka informasi itu harus membantu si penerima dalam apa yang ia usahakan untuk memperolehnya.

b. Ketelitian penyampaian dan pengolahan data:

Dalam menyampaikan dan mengolah data, inti dan pentingnya informasi harus dipertahankan.

c. Waktu

Apakah informasi itu masih up to date?

d. Ruang atau tempat

Apakah informasi itu tersedia dalam ruangan atau tempat yang tepat?

e. Bentuk

Dapatkah informasi itu digunakan secara efektif. Apakah informasi itu menunjukkan hubungan-hubungan yang diperlukan, bidang-bidang yang memerlukan perhatian manajemen? Dan apakah informasi itu menekankan situasi-situasi yang ada hubungannya.

f. Semantik

Apakah hubungan antara kata-kata dan arti yang diinginkan cukup jelas? Apakah ada kemungkinan salah tafsir?

\section{E. Sistem Informasi}

Sistem informasi adalah suatu sistem didalam suatu organisasi yang mempertemukan kebutuhan pengelolaan transaksi harian, mendukung operasi, bersifat manajerial, dan kegiatan strategi dari suatu organisasi dan menyediakan pihak luar tertentu dengan laporan-laporan yang dibutuhkan.

\section{F. WEBSITE}

Pada dasarnya web merupakan suatu kumpulan hyperlink yang menuju dari alamat satu ke alamat lainnya dengan Bahasa HTML (HyperText Markup Languange). Penemu website adalah Sir Timothy John "Tim" Berners-Lee, sedangkan website yang tersambung dengan jaringan, pertama kali muncul pada tahun 1991. Maksud dari Tim ketika membuat website adalah untuk mempermudah tukar menukar dan memperbarui informasi kepada sesama peneliti ditempat dia bekerja. Pada tanggal 30 April 1993, CERN (tempat dimana Tim bekerja) menginformasikan bahwa WWW dapat digunakan secara gratis oleh semua orang yang dapat diakses melalui sebuah software yang disebut browser, seperti internet explore, mozilla firefox, opera dan lain-lain. Website atau situs dapat diartikan sebagai kumpulan halaman-halaman yang digunakan untuk menampilkan informasi teks, gambar diam atau gerak, animasi, suara, dana tau gabungan dari semuanya, baik yang bersifat statis maupun dinamis yang membuat satu rangkaian bangunan yang saling terkait, yang masing-masing dihubungkan dengan jaringan-jaringan halaman. Hubungan antara satu halaman web dengan halaman web yang lainnya disebut Hyperlink.

\section{G. HTML (Hyper Text Markup Languange)}

HTML (HyperText Markup Language) merupakan bahasa pemrograman web yang memiliki sintak atau aturan tertentu dalam menuliskan script atau kode-kode, sehingga browser dapat menampilkan informasi dengan membaca kode-kode HTML. Untuk memudahkan kita dalam mempelajari dasar pemrograman HTML. HTML (Hyper Text Markup Languange) adalah sekumpulan simbolsimbol atau tag-tag yang dituliskan dalam sebuah file yang digunakan untuk menampilkan halaman pada web browser. Tag-tag HTML selalu diawali dengan $<\mathrm{x}>$ dan diakhiri dengan $</ \mathrm{x}>$ dimana $\mathrm{x}$ tag HTML itu seperti b, I, u, dll.

Fungsi HTML adalah sebagai berikut :

1) Membuat halaman web.

2) Menampilkan berbagai informasi di dalam sebuah browser internet.

3) Membuat link menuju halaman web lain dengan kode tertentu (hypertext)

\section{H. CSS (Cascading Style Sheets)}

CSS (Cascading Style Sheets) adalah suatu bahasa yang dikhususkan untuk mengatur gaya atau layout sebuah halaman web. CSS digunakan oleh pembuat halaman web dan juga pengakses halaman web, untuk mendefinisikan warna, huruf layout, dan aspek-aspek presentasi dokumen lainnya. CSS memang didesain untuk memisahkan antara isi dokumen (yang ditulis menggunakan HTML atau bahasa lain yang sejenis) dengan bentuk presentasi dokumen (ditulis dalam CSS). Pemisahan ini memberikan keuntungan akan adanya peningkatan dalam aksesibilitasi isi, menyediakan fleksibilitas lebih, dan pengendalian terhadap spesifikasi karakterisik bentuk presentasi, serta mereduksi kompleksitas dan perulangan-perulangan pada struktur isi. Selain HTML, suatu bentuk bahasa markup lainnya, yaitu XML, juga dapat memanfaatkan CSS ini untuk mengatur gaya tampilan yang diinginkan. Dalam implementasinya, CSS didefinisikan melalui kode-kode style sheet yang dapat disertakan pada file HTML itu sendiri, atau terpisah dari file HTML. Jika terpisah maka file style sheet tersebut harus diberi ekstensi. CSS untuk 
menandai bahwa file tersebut adalah file CSS. Setelah itu, file CSS dapat direfernsi oleh file HTML.

\section{MYSQL}

Pengertian MySQL termasuk ke dalam jenis software pada Relational Database Management System (RDBMS) pada sebuah manajemen database sebagai basis data. Pada sebuah perusahaan misalnya penggunaan sistem informasi dilakukan untuk menyimpan banyak data yang jumlahnya tidak terbatas. Lalu data tersebut dapat diolah untuk kepentingan tertentu secara sedemikian rupa untuk kebutuhan tersebut. MySQL telah sejak lama digunakan sebagai perangkat lunak yang digunakan dalam pengolahan data dengan menggunakan bahasa SQL, sebagai konsep pengoperasian basis data (database). Pada dasarnya MySQL adalah turunan salah satu konsep utama pada basis data yang sebelumnya sudah ada yaitu SQL (Structured Query Language). MySQL adalah sebuah implementasi dari RDBMS yang dapat digunakan secara bebas dibawah lisensi General Public License (GPL). Namun terdapat MySQL yang dijual dibawah lisensi komersial untuk penggunaan fungsi database yang kurang cocok pada konsep GPL.

\section{J. PHP}

PHP merupakan bahasa berbentuk skrip yang ditempatkan dalam server dan diproses di server. Hasilnya akan dikirimkan ke client, tempat pemakai menggunakan browser. PHP dikenal sebagai sebuah bahasa scripting yang menyatu dengan tag-tag HTML, dieksekusi di server, dan digunakan untuk membuat halaman web yang dinamis seperti halnya Active Server Pages (ASP) atau Java Server Pages (JSP). PHP merupakan sebuah perangkat lunak open source (Swastika,2006).

\section{K. XAMPP}

XAMPP adalah perangkat lunak bebas yang mendukung banyak sistem operasi, merupakan kompilasi dari beberapa program. Fungsinya adalah sebagai server yang berdiri sendiri (localhost), yang terdiri atas program Apache HTPP Server, MySQL database, dan penerjemah bahasa yang ditulis dengan bahasa pemrograman PHP dan Perl. Nama XAMPP merupakan singkatan dari X (empat sistem operasi apapun), Apache, MySQL, PHP dan Perl. Program ini tersedia dalam GNU General Public License dan bebas, merupakan web server yang mudah digunakan yang dapat melayani tampilan halaman web yang dinamis (Swastika,2006).

\section{METODOLOGI PENELITIAN}

A. Tempat dan Waktu Penelitian
Penelitian ini dilakukan untuk menyusun tugas akhir, dan dilaksanakan di Kabupaten SITARO.

B. Alat dan Bahan

Tabel 1 Alat dan bahan penelitian

\begin{tabular}{|c|c|c|c|}
\hline No & $\begin{array}{l}\text { Langkah- } \\
\text { Langkah } \\
\text { Aktivitas Riset }\end{array}$ & $\begin{array}{l}\text { Tools yang } \\
\text { digunakan }\end{array}$ & Ket \\
\hline 1. & $\begin{array}{l}\text { Pengembangan } \\
\text { web }\end{array}$ & Laptop & $\begin{array}{l}\text { Spesifikasi : } \\
\text { - Acer Aspire E1- } \\
471 \\
-\quad \text { Processor } \\
\text { Intel(R) } \\
\text { Core(TM) i3- } \\
\text { 2348M 2.30GHz } \\
\text { - RAM 2GB } \\
\text { - OS Windows } 7 \\
32 \text { bit }\end{array}$ \\
\hline 2. & $\begin{array}{l}\text { Perancangan } \\
\text { antarmuka web }\end{array}$ & $\begin{array}{l}\text { HTML, CSS, } \\
\text { Javascript }\end{array}$ & $\begin{array}{l}\text { - HTML } 5 \\
\text { - CSS versi } 3.0\end{array}$ \\
\hline 3. & $\begin{array}{l}\text { Perancangan } \\
\text { logika web }\end{array}$ & PHP & $\begin{array}{lr}\text { PHP versi } & 7.2 .4 \\
\text { (include } & \text { in } \\
\text { XAMPP) } & \\
\end{array}$ \\
\hline 4. & $\begin{array}{l}\text { Perancangan } \\
\text { database web }\end{array}$ & PHP, MySQL & $\begin{array}{lr}\text { PHP versi } & 5.6 .20 \\
\text { (include } & \text { in } \\
\text { XAMPP } & \text { versi } \\
3.2 .2 \text { ) } & \\
\end{array}$ \\
\hline 5. & Web Browser & $\begin{array}{l}\text { Google } \\
\text { Chrome }\end{array}$ & $\begin{array}{l}\text { Google Chrome } \\
\text { Versi } \\
63.0 .3239 .132\end{array}$ \\
\hline 6. & Framework & $\begin{array}{l}\text { - CodeIgniter } \\
\text { - Bootsrap }\end{array}$ & 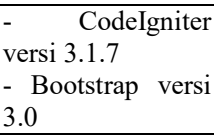 \\
\hline 7. & Teks Editor & Sublime & $\begin{array}{ll}\text { - Sublime build } \\
3143\end{array}$ \\
\hline
\end{tabular}

Prosuder penelitian adalah kerangka kerja berupa langkah-langkah dalam pelaksanaan penelitian. Kerangka kerja yang digunakan menggunakan pendekatan metodologi RAD sehingga terdiri dari tahap analisis persyaratan, tahap RAD Desaign Workshop (Pemodelan), dan tahap Implementasi (Konstruksi).

C. Tahapan pembuatan perangkat lunak

Prosuder penelitian adalah kerangka kerja berupa langkah-langkah dalam pelaksanaan penelitian. Kerangka kerja yang digunakan menggunakan pendekatan metodologi RAD sehingga terdiri dari tahap analisis persyaratan, tahap RAD Desaign Workshop (Pemodelan), dan tahap Implementasi (Konstruksi).

1) Analisa Persyaratan

Tahap ini bertujuan untuk mengidentifikasi kebutuhan, batasan dan objektivitas dari sistem yang akan dibangun, dengan cara mengumpulkan data dari stakeholder. Hasil wawancara dan observasi yang dilakukan dengan beberapa tokoh adat dan masyarakat mengenai kebudayaan yang ada di SITARO, dan beberapa pertanyaan lainnya menjadi acuan dalam penelitian ini. Saat ini belum ada website yang meperkenalkan budaya-budaya di SITARO selain website resmi dari dinas pariwisata. 
Tabel 2 Problem Statement Matrix

\begin{tabular}{|l|l|}
\hline The problem of & $\begin{array}{l}\text { Masih minimnya perhatian } \\
\text { pemerintah terhadap budaya di } \\
\text { SITARO publikasi } \\
\text { Kurangnya y SITARO yang } \\
\text { Kebudayaan di } \\
\text { dapat diakses melalui website. }\end{array}$ \\
\hline Affects & $\begin{array}{l}\text { Informasi dan pengunjung } \\
\text { The impact of which is }\end{array}$ \\
$\begin{array}{l}\text { Kurangnya informasi yang } \\
\text { disediakan, dan belum begitu } \\
\text { terkenal di Indonesia. }\end{array}$ \\
\hline A successful solution would & $\begin{array}{l}\text { Merancang sebuah aplikasi } \\
\text { berbasis web e-culture untuk } \\
\text { mempromosikan budaya yang } \\
\text { ada di SITARO. }\end{array}$ \\
\hline
\end{tabular}

Tahap selanjutnya adalah spesifikasikan kebutuhan pengguna dan sistem melalui pengumpulan data yang dilakukan terhadap stakeholder, sehingga sistem yang akan dibuat akan sesuai dengan yang dibutuhkan oleh pengguna. Hasil dari langkah ini adalah berupa spesifikasi pengguna yang dapat dilihat pada tabel 2, dan persyaratan sistem pada tabel 3

Tabel 3.4 Spesifikasi Pengguna

\begin{tabular}{|l|l|l|}
\hline Pengguna & Peran & Tanggung Jawab \\
\hline Admin & Admin & $\begin{array}{l}\text { Bertanggung jawab mengelolah } \\
\text { database berupa penambahan } \\
\text { data, edit data, hapus data, dan } \\
\text { menyediakan informasi pada web } \\
\text { e-culture Kab. SITARO }\end{array}$ \\
\hline Masyarakat & User & $\begin{array}{l}\text { Aktor yang menggunakan web e- } \\
\text { culture Kab. SITARO untuk } \\
\text { melihat informasi budaya. }\end{array}$ \\
\hline
\end{tabular}

2) RAD (Rapid Application Development)

Rapid Application Development (RAD) atau pengembangan aplikasi cepat, dikemukakan oleh Kendall adalah pendekatan berorientasi objek untuk pengembangan sistem yang meliputi metode pengembangan serta perangkat lunak. Kendal dan Kendall melihat RAD sebagai metodologi pengembangan sistem yang berusaha untuk mengatasi perubahan persyaratan kebutuhan user dan merekomendasikan RAD untuk mengembangkan aplikasi berbasis web. Menurut Pressman, RAD merupakan model proses lunak yang menekankan pada daur pengembangan hidup yang singkat. Sedangkan menurut Schach, Suatu model rapid prototype, merupakan working model dimana sebagian fungsional aplikasi sudah berjalan.

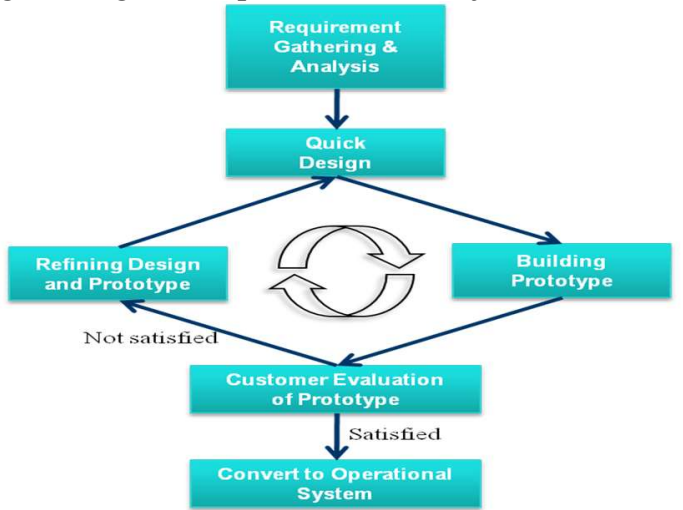

Gambar 1 Metodologi RAD web-prototyping(Tim Pengembang Portal Resmi Unsrat : 2015)

Ada 4 tahapan yang harus dilakukan pada metodologi RAD yaitu sebagai berikut :

a. Analisa Persyaratan

Tahap ini memiliki tujuan untuk mengidentifikasikan kebutuhan pengguna, spesifikasi sistem melalui observasi dan pengumpulan data yang dilakukan terhadap stakeholders. Selain itu analisis persyaratan juga bertujuan untuk mendefinisikan persyaratan user dan sistem. Hasil akhir dari analisis persyaratan yaitu spesifikasi awal dari persyaratan user dan sistem.

b. Analisis Modeling

Tahap ini memiliki tujuan untuk menganalisis semua kegiatan dalam arsitektur sistem secara keseluruhan dengan melibatkan identifikasi dan deskripsi abstraksi sistem perangkat lunak yang mendasar dan hubungan-hubungannya. Hasil akhir dari analisis modeling yaitu diagram model logis dari sistem yang sedang berjalan, diantaranya use case diagrams, class diagram, dan sequence diagrams.

c. Desain Modelling

Tahap ini memiliki tujuan untuk mendesain modeling dengan melakukan perancangan sistem berdasarkan analisis yang telah dilakukan sebelumnya. Tahap analisis dan desain mengalami perulangan hingga diperoleh rancangan sistem yang benarbenar memenuhi kebutuhan.

d. Konstruksi

Tahap ini memiliki tujuan untuk menunjukkan platform, hardware, software, batasan implementasi, dan rencana pengujian yang telah dibangun sesuai dengan spesifikasi analisis dan perancangan yang telah diidentifikasi sebelumnya. 
3)

1. Use case Diagram

Use case diagram dirancang untuk menunjukkan secara umum fungsi dan tanggung jawab masing-masing aktor dalam web e-culture yang akan dirancang. Use case diagram dari web e-culture dapat dilihat pada gambar 2

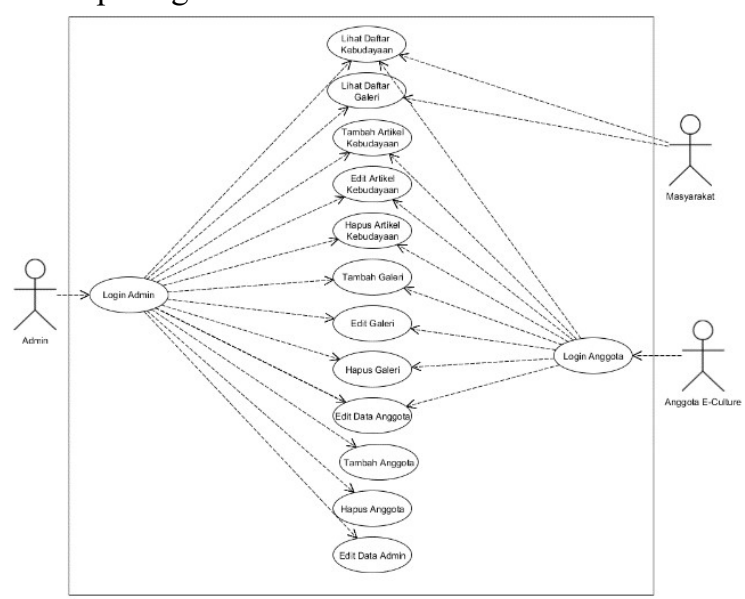

Gambar 2 Use Case Diagram

Gambar di atas menunjukkan use case diagram yang terdiri dari beberapa use case yang akan dijabarkan pada use description yang merupakan penjelasan terhadap tiap use case.

2. Use Case Description

Use case description merupakan tabel penjelasan tentang use case yang ada pada use case diagram.

3. Class Diagram

Class diagram dapat dilihat pada gambar berikut :

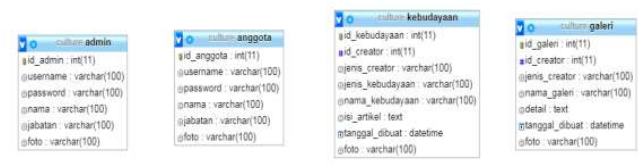

Gambar 3 Class Diagram

4. Activity Diagram

Actifity Diagram dirancang untuk menunjukan proses bisnis yang akan di rancang sesuai dengan keinginan stakeholder. Actifity diagram ini juga merupakan usulan proses bisnis.
Actifity dari web e-culture dapat dilihat pada gambar 3

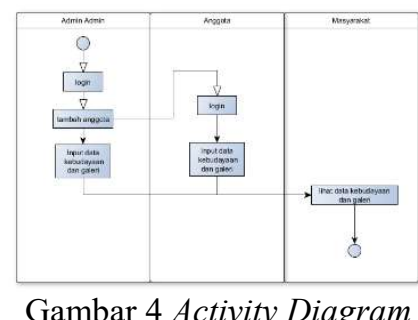

Gambar 4 Activity Diagram

\section{HASIL DAN PEMBAHASAN}

A. Implementasi Antar Muka Web

Di bawah ini adalah tampilan depan yang terdapat pada menu beranda.

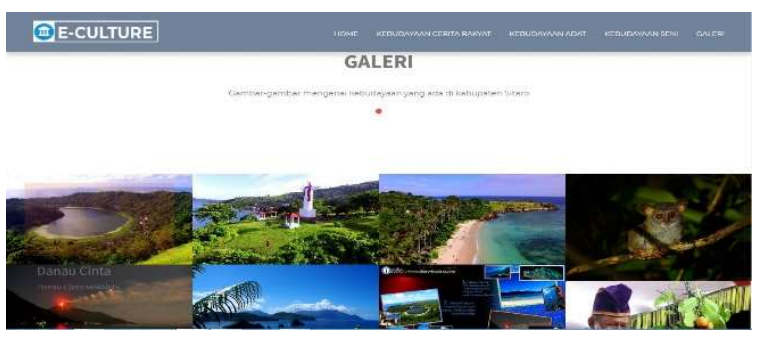

Gambar 5 Tampilan halaman Galeri
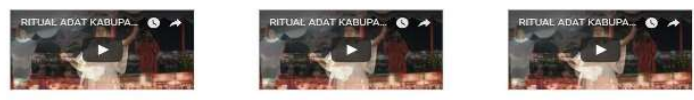

wan

Gambar 6 Gambar Tampilan Halaman Video

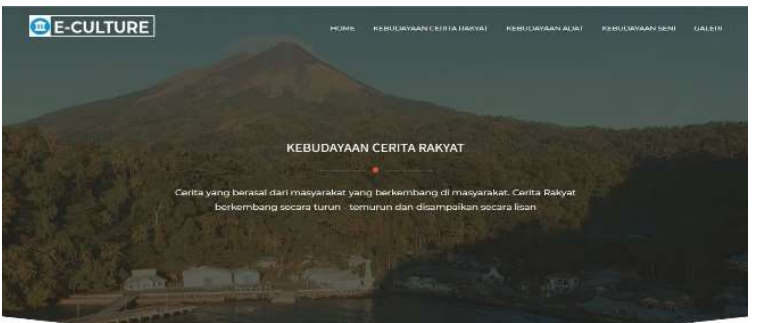


Gambar 7 Gambar Tampilan menu Kebudayaan Cerita Rakyat
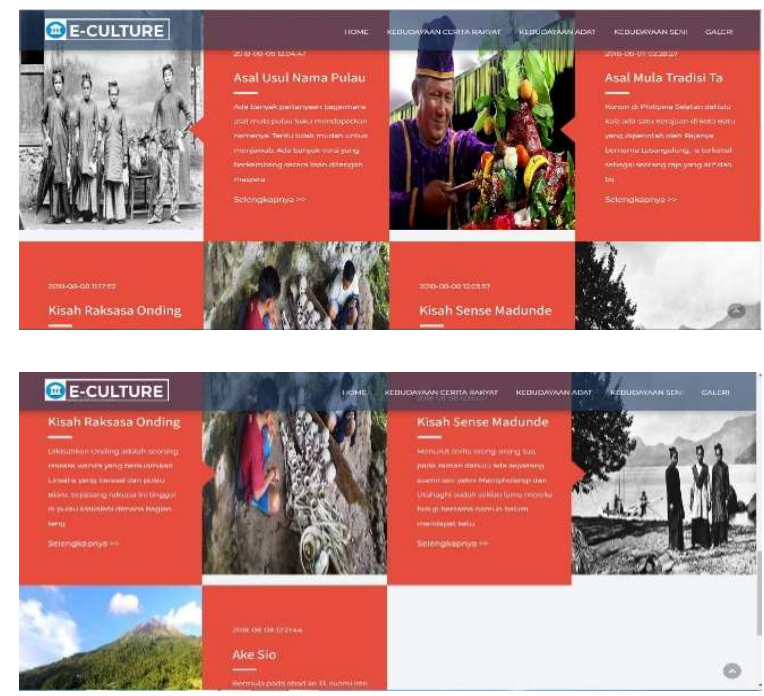

Gambar 9 Gambar Tampilan definisi Kebudayaan Cerita Rakyat

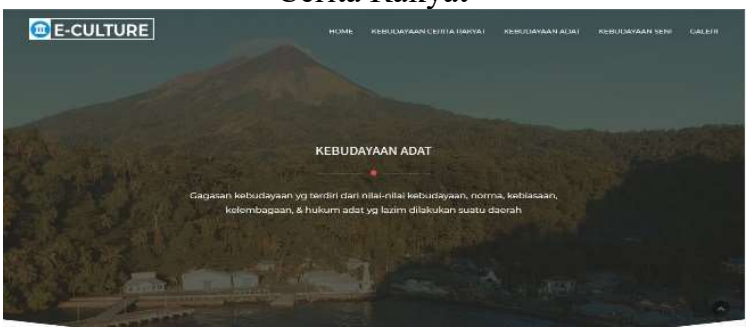

Gambar 10 Gambar Tampilan Menu Kebudayaan Adat

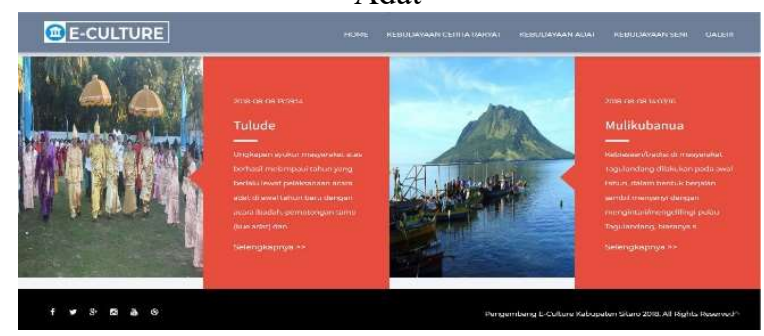

Gambar 11 gambar tampilan menu definisi Kebudayaan Adat

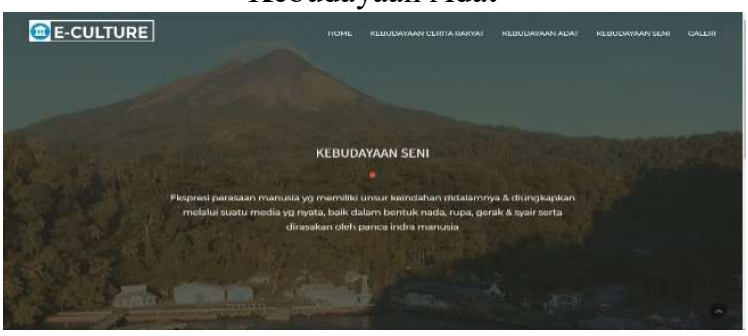

Gambar 12 Gambar Tampilan menu Kebudayaan Seni

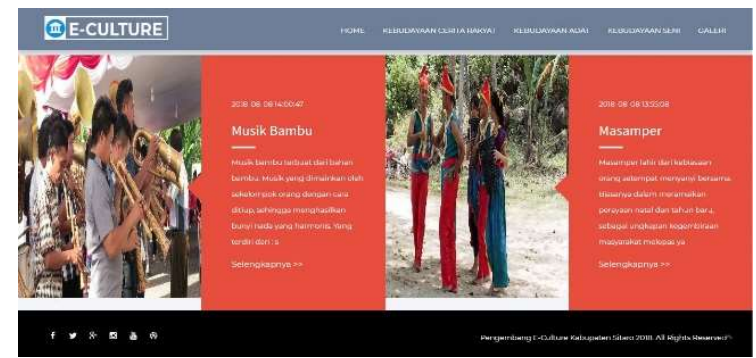

Gambar 13 Gambar Tampilan definisi Kebudayaan Seni

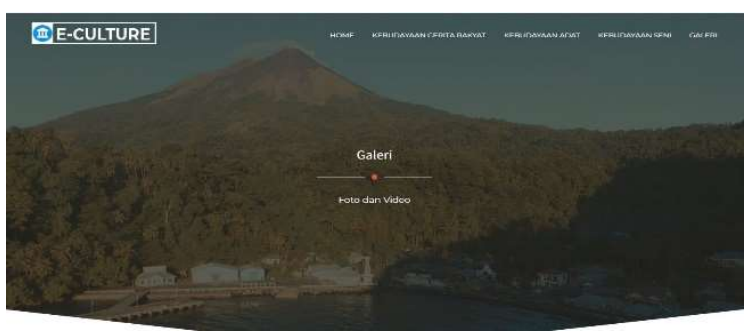

Gambar 14 Gambar Tampilan Menu Galeri

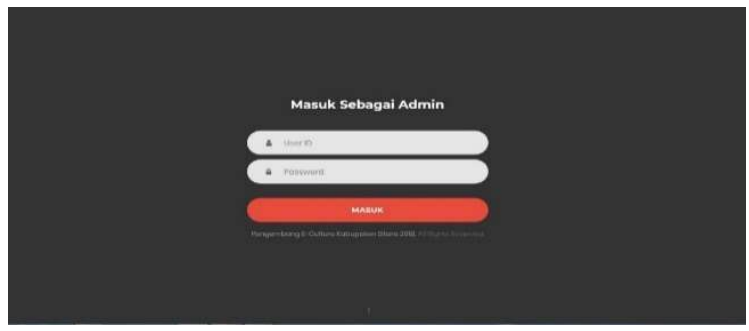

Gambar 15 gambar Tampilan masuk sebagai admin

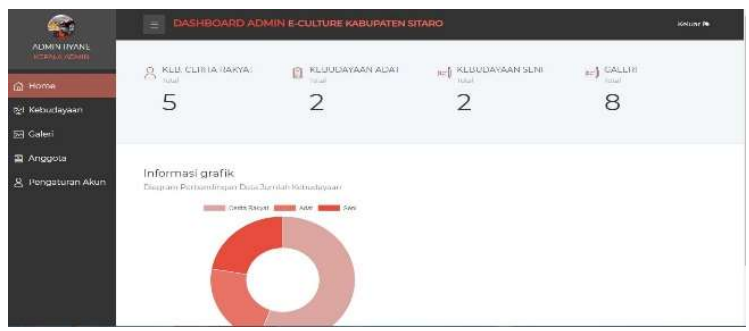

Gambar 16 gambar Tampilan Menu Home Admin

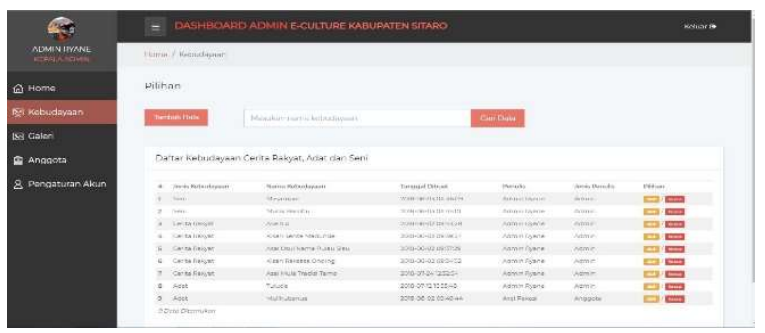


Gambar 17 gambar tampilan Menu Kebudayaan Admin

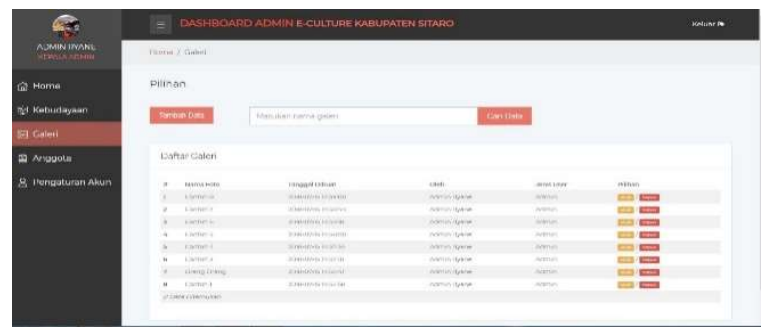

Gambar 18 Gambar Tampilan menu Galeri Admin

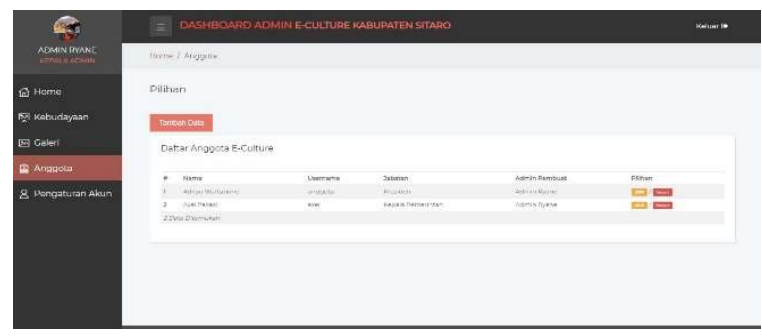

Gambar 19 Gambar Tampilan menu Anggota Admin

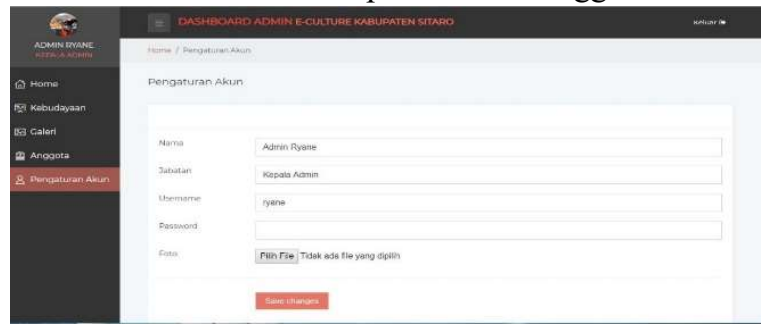

Gambar 20 Gambar Tampilan menu Pengaturan Akun admin

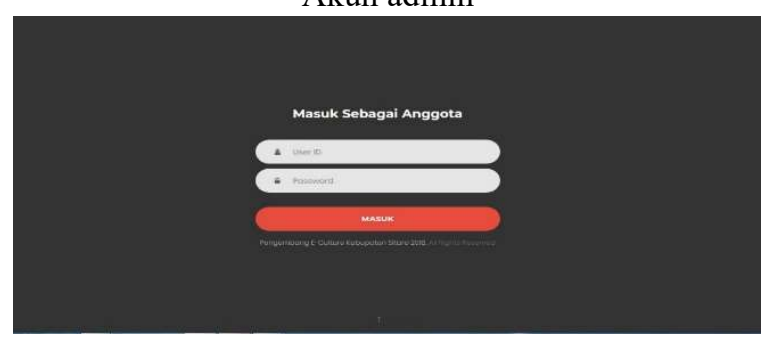

Gambar 21 Gambar Tampilan Masuk sebagai anggota

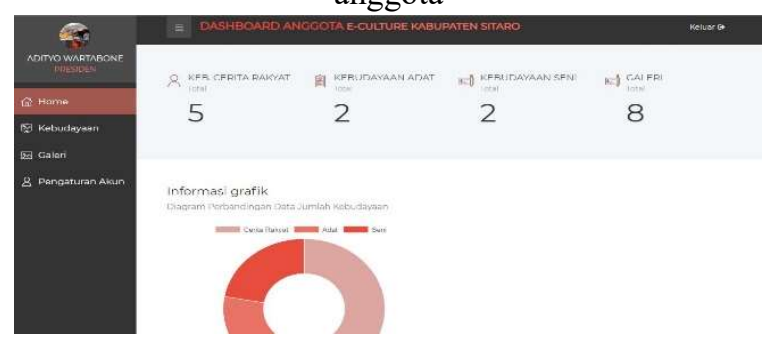

Gambar 22 Gambar Tampilan home sebagai anggota

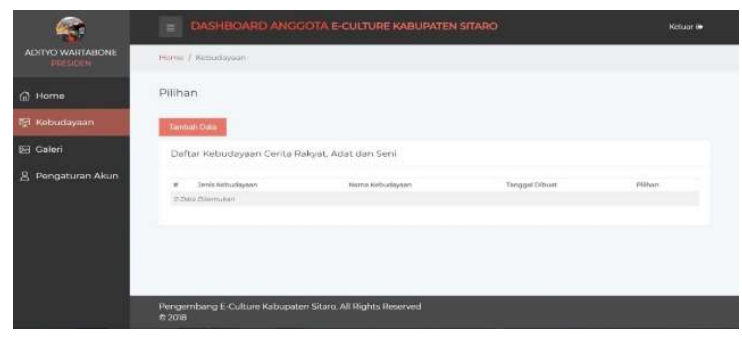

Gambar 23 Gambar Tampilan Kebudayaan sebagai anggota

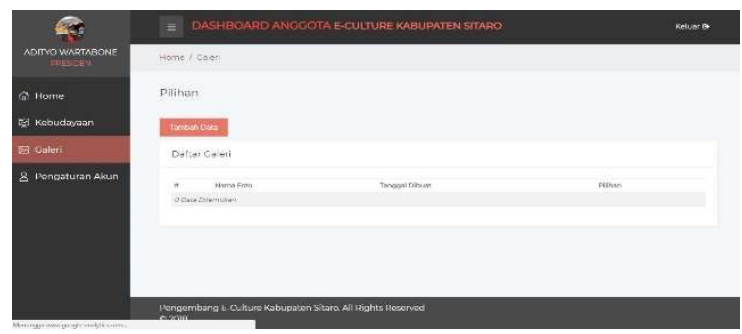

Gambar 24 gambar Tampilan Galeri sebagai anngota

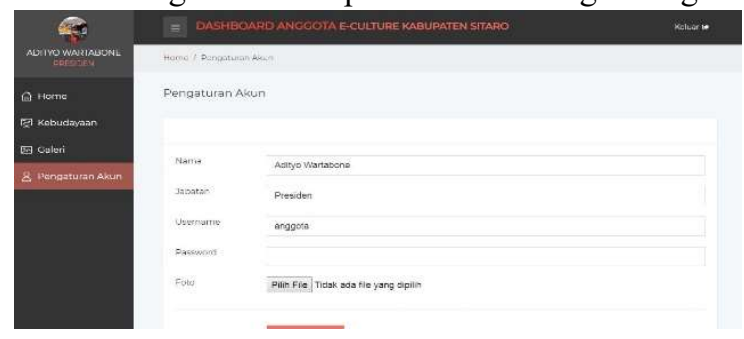

Gambar 25 gambar Tampilan pengaturan akun sebagai anggota

\section{PENUTUP}

\section{A. Kesimpulan}

Penelitian dengan judul "Aplikasi Pengenalan Pakaian Adat Daerah Indonesia Menggunakan Augmented Reality 3 Dimensi" telah berhasil dibangun dengan menggunakan teknologi markerless augmented reality.

Aplikasi Pengenalan Pakaian Adat Indonesia 3 Dimensi dapat diakses melalui perangkat mobile atau smartphone android. Aplikasi pengenalan pakaian adat Indonesia 3 Dimensi ini dapat membantu dalam menambah pengetahuan tentang pakaian-pakaian adat di Indonesia dan cara memperkenalkannya dengan menggunakan teknologi augmented reality 3 dimensi. 
B. Saran

1) Pengembangan selanjutnya yaitu menambahkan beberapa provinsi lagi karena aplikasi ini cuma membuat 16 provinsi di Indonesia serta objek karakter 3 dimensi sudah harus disertai dengan animasinya.

2) Pengembangan platform harus lebih luas seperti dapat berjalan di iOS, windows phone, bahkan yang lainnya.

3) Untuk ukuran dari aplikasi diushakan dibuat lebih kecil lagi agar tidak membutuhkan waktu yang lama dalam menjalankan aplikasi tersebut.

\section{DAFTAR REFERENSI}

[1] Kamus besar Bahasa Indonesia, 1998:5,6. Kebudayaan Adat

[2] Susanto Agus. 2017. Biografi Eris Munandar. Purwekerto : FKIP UMP

[3] Arsul. 2015. E-Tourism Kabupaten Pulai Morotai. Manado : Jurusan Teknik Elektro Universitas Sam Ratulangi, e-journal Teknik Elektro dan Komputer, ISSN : 2301-8402

[4] Lesomar Fransiskus. 2015. Rancang Bangun Portal Web Pariwisata Maluku Tenggara, ejournal Teknik Informatika, Volume 6, No. 1, ISSN : 2301-8364

[5] Maru Gidion Mister. 2012. Asal Usul Siau. DIY : Lembah Manah

[6] Kendall, K E. dan Kendall, J. E. 2010. Analisis \& Perancangan Sistem. Jakarta : PT. Indeks.

[7] Pressman. 2002. Rekayasa Perangkat Lunak Pendekatan Praktisi (Buku) : Yogyakarta

[8] Dalalu Sintia. 2017. Sistem Informasi Terpadu Fakultas Teknik Universitas Sam Ratulangi. Manado : Fakultas Teknik Program Studi Informatika Universitas Sam Ratulangi.

\section{SEKILAS TENTANG PENULIS}

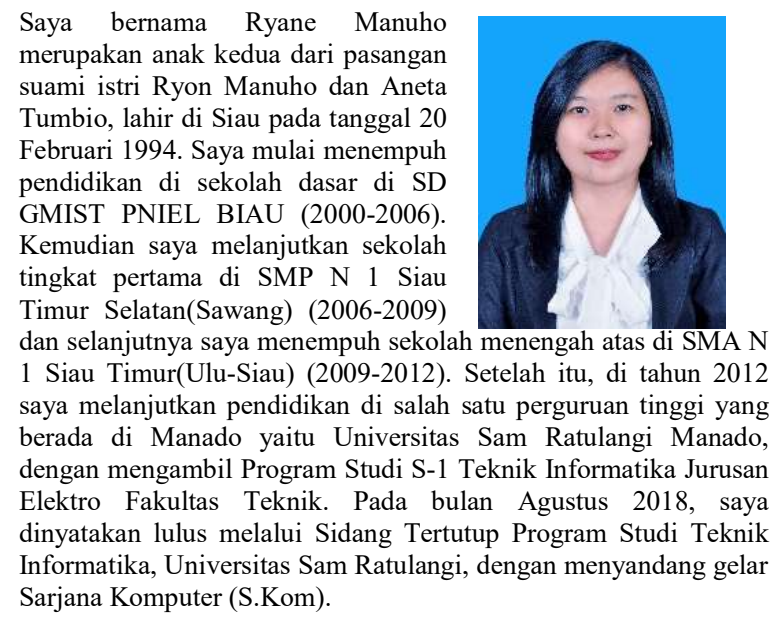

